\title{
Citizen involvement in urban planning process in Russia
}

\author{
Elena Tselishcheva ${ }^{1, *}$, Elena Kondyukova $^{2}$, Aleksandr Pobedin $^{1}$, and Faina Babanova ${ }^{2}$ \\ ${ }^{1}$ Ural Institute of Management, Russian Presidential Academy of National Economy and Public Administration, 66, 8 Marta st., \\ Yekaterinburg, 620144 Russian Federation \\ ${ }^{2}$ Ural Federal University named after the first President of Russia Boris Yeltsin, 19, Mira st., Yekaterinburg, 620002, Russian \\ Federation
}

\begin{abstract}
The paper examines citizen involvement in the urban planning process. Although different forms of public control have been established in Russian legislation application of western approaches for urban planning process, organizations face low interest from local communities, on the one hand, and inability of local authorities to work with public initiative, on the other. The research is based on the multidisciplinary approach. The methodology includes deliberative democracy, advocacy planning conceptions, spatial economic theory, and urban studies. Methods of system, institutional, comparative analysis, focus groups and content analysis are used. The research has been conducted based on the materials of public space renovation projects in some major cities regional capitals in Russia. The empirical base of the research includes acts regulating the urban planning sphere, mass media content about urban space renovation projects, materials from focus groups with representatives from local authorities and initiative citizen groups. The paper represent results of the international scientific research project "Legitimacy, urban planning and sustainability in Russia and Sweden (LUPSRUSS)" which was funded by the Swedish International Centre for Local Democracy (ICLD).
\end{abstract}

\section{Introduction}

If a country declares sustainable development goals in the constitution, it will have to design a communication mechanism between citizens and authorities. Western world countries spent more than hundred years to minimize conflicts of interest, and even after it, the problem does not entirely disappear.

While contemporary researchers apply to urban postindustrialism the conception with a global symbol of digital-cities and social innovations, discuss different aspects of innovative breakthrough, some Russian citizens still has not access to elementary communal facilities.

Social inequity has been growing up during the last two decades. Systematic economic, political and environmental turbulence takes away citizens' belief in a positive world picture of the future. In spite of the fact that turbulence can lead to creation of new structures, lack of stability in the transition period creates fear and rejection [1].

In this regard, cooperation between citizens and authorities depends on the level of development of social institutes and cover all aspects of life.

Participatory urban planning is one of the public cooperation forms. It indicates growing civil identity, which produce new models of communication between citizens and government. Authorities in western countries came a long way to develop trust relationship with citizens. Russia is at the start of this process. It will have to strengthen civil identity first through education, conscience and negotiation.

\section{Conception of citizen engagement in urban planning process}

Urban planning includes three aspects: 1) development of abandoned urban spaces; 2) manner of interaction between citizens and government in the process of urban plans actualization; 3) formation of civil identity in relation to public spaces development/redevelopment projects. The last aspect is the result of both previous ones, because the truth is born in a dialogue, communication process and even conflicts. Only through that, we can achieve a compromise - one of the alternative projects that satisfy all urban planning process stakeholders.

Participatory urban planning conception reflected in scientific publications by Davidoff P. (advocacy planning theory), Krumholz N. (equity planning theory), Lefebvre H., Harvey D., Lynch K. (right to the city conception), Arnstein S. (participatory decision making theory, the model «Ladder of citizen participation»), Sandercock L. (community planning and multiculturalism), Healy P. (collaborative planning conception) [2].

In 1968 Lefebvre $H$ published the monograph «Le Droit à la ville». He was the French sociologist and philosopher, who introduced the concepts of the right to the city and the production of social space [3]. In his

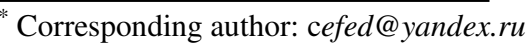


monograph he appealed to idea that citizens must be included in decision making process regarding to urban planning projects and formulated citizens' right to the city resources. Due to his publications, urban space became the form of social phenomena (space for social processes and social events) [4].

Although «the right to the city» conception appeared more than half of the century ago, Lefebvre $\mathrm{H}$. became known in urban planning theory with some delay, that, in our opinion, was due to unavailability of society understand his ideas before achievement of higher level of civic engagement development. Tsunami wave of public initiative movement in urban planning covered the USA, Europe and Latin America at the end of the XX century and then inflamed Middle East in megacities Beirut and Istanbul [5].

Contemporary researchers criticize «the right to the city» conception for excessive radicalism and engagement of conflicting citizen groups in planning process because leads to intensification of social conflicts. For example, Pursell M. wrote: «I do not present the right to the city as the only or the best strategy for renewing urban democracy» [6]. On the other hand, citizens knew situation from the origin, and their well-reasoned arguments allow prevent «capture of the right to the city» by bureaucrats.

Nowadays on practice bureaucrats from administrative structures can still suppose that the scale of strategic urban plans (especially in mega-cities) is impossible for understanding by ordinary people without professional knowledge. Inhabitants cannot catch the essence of development project documents. That is why it is necessary to minimize their engagement in the decision-making process. But, even 50 years ago researchers warned that ignoring public interests at the times of growing civic conscience can lead to negative socio-economic consequences. Contemporary researchers, representatives of the new stage of urban theory, warn that citizens in mega-cities have got selfconnection opportunity through social networks and other social innovations [7].

Economic geographer Harvey D. paid special attention to socio-psychological aspects of urbanization. Political struggle for «the right to the city» affects civic identity and changes not only living space but also a social relations system [8].

Authors of the advocacy planning theory [9] and equity planning conception [10] borrowed ideas from deliberative democracy theory, and found brilliant practical implementation in court cases in Europe and the United States in the 1970-90s. The court cases were mostly about protection of groups with a lower socioeconomic status from negative consequences of urban space renovation projects or industrial environment pollution, which can lead to degradation of quality of life. Advocacy planning became both theory and practice of judicial and social support for vulnerable groups of citizens.

Healey P. developed a collaborative planning idea and put a special emphasis on necessity to involve all stakeholders in the urban planning process [11]. In his research he described reasons of urban conflicts and ways of its solution. Technical progress and innovations are considered as conflict reasons because it can lead to negative consequences and directly or implicitly affect all urban inhabitants. For example, conflicts about environment pollution reflect dissatisfaction of citizens with the loss of property benefits and their fear of the future. Healey P. suggested discuss consequences of urban projects in a form of mediation with the involvement of independent experts.

Canadian researcher L. Sandercock analyzed multicultural aspects of agglomerations' development and also was concerned about two negative tendencies: declination of the state's responsibility to the population and growing pressure from developers on decisions related to important urban development projects [12]. She wrote that big companies receive simplified access to redevelopment of public urban spaces.

In the middle of the 1960-s S. Arnstein, researcher and consultant of USA government on racial and social segregation, proposed the model «ladder of citizens participation». The model demonstrates different levels of participatory planning development and remains actual and applicable to characteristic of today public participation forms in different countries.

Unfortunately this scientific direction is poorly presented in works of Russian researchers.

\section{Development of civic engagement in Russia}

The Russian urban planning system for a long time reflected the Soviet Union's custom to plan urban development without asking habitants. The urban planning process was the privilege of authorities until the mid of the XX century, but after that some intention to consult with scientists and experts appeared. Risks of citizens' protest against some projects were smoothed out by active promotion of the picture of bright socialistic future and by call for total public welfare in the Soviet Union.

Initiative passed to developers in the post-Soviet period. They reshaped city maps as they wanted, built houses extremely tightly to each other, without taking into account the increasing burden on social and communal infrastructure. They could destroy parks and other green zones. This practice leads to significant declining of quality of life [13].

Participatory urban planning and development became popular and supported by authorities during the last few years. Now we can say that cooperation between authorities and citizens considered as a mechanism for monitoring the quality of construction projects and improvement projects, and as a tool to reduce social tension.

Intention to maintain social sustainability leads to understanding that civil city-management is impossible without deliberation. Habitants have right to the city they can use existing spaces and transform them so they meet the needs of real people [3].

In spite of the fact that Russian patrician accept deliberation idea and know about public deliberation of 
urban planning documents with citizens, business, scientists, initiative projects were quite rarely implemented in real life.

During the research project we analyzed different forms of civic engagement in urban development planning by the example of largest Russian cities regional capitals. In all cities, citizens can participate in the development of the following territorial planning documents:

- strategic plans of municipal socio-economic development (including a special chapter about spatial development);

- urban plans (general plans, land use and development plans);

- initiative budgeting projects (usually small projects in different spheres, only projects in the sphere related to territorial development were included in our research (for example, children play grounds construction, monuments renovation);

- projects of public spaces and semi-public spaces development (renovation) financed through the national project «Comfortable urban environment». The project includes projects in 40 Russian cities.

Public hearings, public deliberation, questionnaires, collection of signatures for support or against particular urban development projects became most popular forms in Russian cities for discussion of the above-mentioned documents.

Federal Law No. 212-FZ «About the basis foundations of public control system in the Russian Federation» (was signed and published in 2014) establishes different forms of civic engagement. The list of forms is opened so it is possible to develop the public control system further and implement new forms. Regional and municipal governments establish entire forms of public control in subnational legislation. Public control forms established in legislation and used in daytoday practice are not the same (figure 1).

\section{FORMS OF PUBLIC PARTICIPATION}

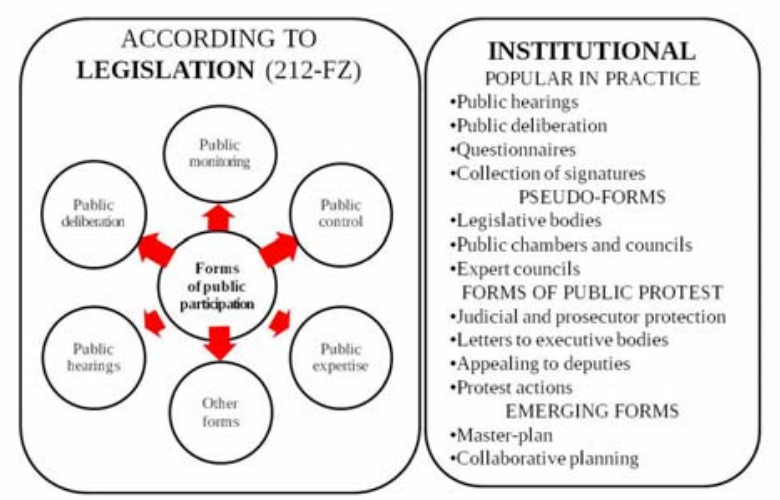

Fig. 1. Forms of public participation

Consideration of urban development documents with deputies (as they are elected representatives of citizens), experts and public council's officials equate to public participation forms.

From our point of view the total forced formation of public chambers and public councils in Russia is an attempt to impose from above convenient and acceptable to the authorities public participation forms. Unfortunately these forms don't reflect the interests of different citizens groups and have lack of feedback.

According to Federal Law No. 172-FZ «About strategic planning in Russian Federation» all long-term perspective documents or significant-volume documents (for example, strategies of socio-economic development, spatial development plans, complex development plans) are ought to be negotiated with:

- legislative bodies (deputies);

- scientific and professional community (expert councils and public councils created by executive bodies).

Both pseudo-forms of public participation identify opinion of professional groups, which does not always coincide with the opinion of citizens. We recommend using this forms in addition to the mentioned above expert councils and negotiation with deputies allow one to examine in detail results of direct communication with habitants (public hearings, deliberation, questionnaires). Local authorities should recruit experts and deputies as mediators in the urban planning process.

The role of public chambers, public councils and expert councils in the participatory urban planning process worth a separate research work.

Municipal authorities often use public hearings and public deliberation for consideration of less-volume urban planning documents with habitants.

The concept of public hearings and public deliberation is related to the long-standing traditions of western sociology, but does not correspond to totalitarianism conception, which still exist in the postSoviet space. Some researchers note that public hearings in Russian cities have formal character and their results can't affect decisions taken by authorities [14]. Shortcomings of public hearings include (see figure 2):

- late notification about the hearings' start;

- conducting of hearings in hardly accessible places in inappropriate time (working hours as usual);

- informing habitants about hearings in newspapers who never read;

- using special incomprehensible for ordinary people terminology during project presentation;

- ignoring remarks and questions from the audience.

Local governments and developers consider public hearings as excessive work that costs the time and money (a lot of noise without result).

Among public hearings participants can be a significant number of representatives from developers (have a clear financial interest), as well as public and political organizations (since any confrontational situation can be used to realize political ambitions). There were cases when in order to create a positive project image special «participants» were hired and paid for the «right» vote.

Municipal authorities consider public deliberation (according to Russian legislation means Internet discussions about urban development projects on a special Internet portal) as a better alternative to public hearings. It allow increasing availability for participants, 
informing citizens about urban development projects and simplifying the work of government.

Inhabitants had to visit city hall (or other specified location) to participate in public hearings and vote for city-planning changes (for example transfer of land from one category to other). They can ask questions and communicate directly with officials.

Public deliberation allows one to do all the same through the Internet. Loss of some active participants because of their computer illiteracy (mainly elderly population) is compensated with a vengeance by inclusion of a significant number of people who cannot attend public hearings because of their employment.

For participation in public deliberation the registration is required (you must enter personal data, including residence). That allows one to reduce risks of fraud when counting votes. On the other hand inhabitants without «permanent residence» as well as public organizations, groups of citizens (associations, clubs and etc.) are excluded from the communication.

Local authorities in the cities we studied promoting public deliberation instead of public hearings. Nonetheless, experts note that change of communication channel (virtual space instead of direct communication) does not deprive this form from inherent disadvantages of public hearings. Longstanding traditions administrate from above, personal interests of some officials and necessity spend organizational resources on «virtual» troubles cause local authorities' unwillingness to develop true participatory urban planning. Municipal authorities can make decisions contrary to the resolution of public discussion.

The situation is complicated by the fact that ordinary inhabitants don't have professional knowledge in the construction and urban development. Public discussion participants (both public hearings and public deliberation) only criticize urban development projects and have not practically applicable suggestions.

All the shortcomings as well as the advisory nature of public discussions' resolutions cause the loss of interest from inhabitants. Experts note a very low share of citizens involved in urban planning projects in Russia.

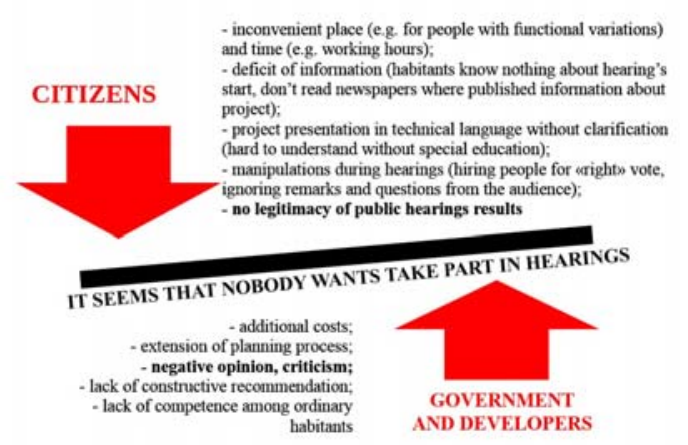

Fig. 2. Shortcomings of public hearings and public deliberation from different points of view

Bad examples of public discussions in big Russian cities can be classified as the «manipulation» and «therapy» stages of the model by S. Arnstein called
«Ladder of citizens' participation» [15]. Public discussions in this cases «teach» and «treat» citizens and don't allow them take active part in urban development planning as well in projects implementation.

In practice habitants can express their opinion on different aspects of urban life very actively, have a strong position «for» or «against» some projects but they are not ready to make suggestions. That is why questionnaires and collecting signatures are very popular forms of public opinion expression in Russia. Questionnaires are conducted by municipal governments and as usual closely related to a place of inhabitants' residence (limited locality). Other form - collecting signatures - is usually initiated by active citizens (group of citizens) who want to promote some suggestion or to express their disagreement with some decision.

Civil society can affect decisions related to urban construction or development projects through deputies as public representatives or by applying (directly or in written form) to executive bodies, prosecutor's office. The mechanism of judicial protection is also can be used. Result of conducted focus-groups shows that people consider applying to deputies as ineffective and other specified above forms as very expensive, but possible in the extreme. All these forms indicate lack (or insufficient level) of communication between local authorities and citizens and used by citizens when local authorities make decisions contrary to their opinion.

Protest actions are even a more vivid form of expression citizens' disagreement in relation to urban development projects which implemented contrary to public opinion.

Sustainable development of cities creates a natural background for civic conscience growth and supported by a new generations «Y» and «Z» with IT-thinking [16]. This dilemma particularly affects megalopolises as dynamic business centers with implementation of fantastic ideas in both urban planning and business communications [17].

The new generation is opened to deliberation ideas, looks for comfortable living conditions, able to exchange information quickly. In this context society will develop along the way of strengthening civil self-organization.

Government which grabs «right to the city» and doesn't look for social compromise between all groups of stakeholders cannot be innovative and doesn't correspond to new needs of modern socium.

\section{Results and discussion}

We recommend increase effectiveness of public hearings and public deliberations. This allow moving from nonparticipation to tokenism stage (when citizens can at least be heard) according to the model of citizens' participation by S. Arnstein.

We recommend local governments pay more attention to small urban development projects, control procedures of their public discussion (for example, through interaction with deputies or developers). Local authorities should pay special attention to the following public discussion aspects: 

earliest;

- engage residents at all project cycle stages from the

- submit for public discussion clear and close to particular groups of citizen projects, divide scale projects into small, discuss separate aspects of whole project in focus-groups, make special surveys and consultations with experts (accessibility of renovated area for people with functional variations, bicycle roads, organization different zones for sport, promenade or play-grounds in parks and etc.);

- conduct regular public discussions with habitants at residential quarter, microdistrict level.

Local authorities should always keep in minds that legitimacy of public discussions depends rather on project changes under the pressure of public opinion, not on formal procedures [18].

New forms of public discussion (master plan development, participatory design, etc.) were introduced in some big Russian cities last years for public-space development projects. The Russian Agency of Strategic Initiatives (large non-profit organization in Russia responsible for stimulation of economic development) was developed and the Federal Ministry of construction, housing and communal services approved special methodological recommendations «The basic model for public participation process organization». This document details the national project «Comfortable urban environment». The positive experience of their approbation is described in the works of a number of authors [19, 20].

Participatory design conducted in small groups (in the form of project seminars) supposes organization series of meetings with residents throughout the whole project cycle (minimum three meetings), starting from the earliest stage of the project cycle where people formulate initial requirements (must be included in technical specification to the project development documents).

The master plan as a document is similar to a general city plan but is not included in the legally established list of urban planning documents. Master plan designers (usually consulting companies, architect bureaus) conduct sociological surveys of residents and other stakeholders (groups of active citizens, non-profit or public organizations), meetings or seminars. Public discussions are carried out at all stages of project cycle (development of the project concept, detailed planning, presentation of project results) in small groups. This form of participatory planning is applicable not only in urban development projects, but also in transport infrastructure development, ecology, stimulation of economic development projects. Public opinion forms base on the project improvement and citizens feel responsibility for positive urban development as if they are co-authors.

In spite of the fact that new forms of participatory urban planning became very popular in public space development project, it is still very hard to transfer their results into a general city plan. Other significant disadvantage of these forms is that they need a significant amount of time and resources.

\section{Conclusion}

Various aspects of participatory urban planning are described in papers of foreign researchers. This research direction has been developing for more than 50 years, but due to specifics of public administration, it was not actual in Russia for a long time.

Legally established forms of public participation with special accent on public chambers and councils don't correspond to institutional forms used in practice. Presentation of territorial planning documents to expert councils and in legislation bodies is widespread in practice and considered as public participation. Public hearings and public deliberation procedures, questionnaires are formal, their results don't affect the final decision-making.

Socio-political transformation in Russia requires further improvement of public participation forms. Municipal authorities receive significant benefit when organizing the social communication process correctly. First of all, residents have important for urban planners information and can help actualize it. Second, residents who take part in the project deliberation are often ready to make a personal contribution to its implementation.

Foreign scientists made significant contribution in this research direction development, but it still needs to be clarified:

- terminology (it is necessary to analyze the definitions of public participation forms used in scientific papers and legal acts);

- indicators and methodology for evaluation the degree and effectiveness of citizens' involvement in the processes of participatory urban planning.

Recommendations of western authors based on outdated 50 years old planning practice should be adapted to actual Russian conditions before application. For example the range of urban development stakeholders in Russia today includes not only residents.

First of all, functions of communication between state and citizens in Russia can belong to organized groups of people (public non-profit non-governmental organizations). Unfortunately they are currently excluded from deliberation because of gaps in legislation.

Second, significant attention must be paid to development of direct communication between citizens and big companies - urban development investors. Big companies in regional capital cities and also in monocities participate actively in housing building and public space development/renovation projects.

We should pay special attention to the new forms of public participation developing very fast.

\section{References}

1. L. Leonova, E. Alpatova, T. Rutkauskas, S. Kowalczyk, International Conference on Sustainable Cities (ICSC), 6, (2016).

2. P. Akimov, Urban research and practice, Pilot Issue (2015). 
3. H. Lefebvre, Le droit à la ville. Collection Société et Urbanisme (Paris, Anthropos, 1968).

4. S. Konchekov, 2018. Architecture and modern information technologies, 1(42), (2018).

5. J. Uitermark, W. Nicholls, M. Loopmans, Environment and Planning, 44 (11) (2012).

6. M. Pursel, GeoJournal, 58 (2-3), (2003).

7. F. Laloux, Reinventing Organizations: A Guide to Creating Organizations Inspired by the Next Stage of Human Consciousness (Nelson Parker, 2014).

8. D. Harvey, Cosmopolitanism and the Geographies of freedom (Columbia University Press. 2009).

9. P. Davidoff, Journal of the American Institutes of Planners, 31(4) (1965).

10. N. Krumholz, Journal of Architectural and Planning Research, 4, (1986).

11. P. Healey, Collaborative Planning: Shaping Places in Fragmented Societies ( $2^{\text {nd }}$ Edition. Macmillan International Higher Education. 2006).

12. L. Sandercock, Planning Theory and Practice, 6(4), (2005).

13. R. Mukhatinova, Youth scientific bulletin, 12, (2016).

14. I. Medvedev, Zakon, 3, (2018).

15. S. Arnstein, Journal of American Planning Association, 35(4), (1969).

16. E. Shershneva, A. Gabitova, International Conference on Continuing education for sustainable development: new challenge, May 2324, in Nur-Sultan, Kazakhstan, (2019).

17. E. Kondyukova, E. Shershneva, WHATT, 10, 4. (2018).

18. A. Vasilache, Case studies from small and midsized European cities. (Belgrade, Serbia. 2010).

19. A. Lozhkin, Moscow Urban Forum, December 7, (Moscow, Russia, 2013).

20. A. Schukin, The Expert, 40 (1091), (2018). 